\title{
Роль диффузии ионов в прямой фемтосекундной лазерной записи в теллуритных стеклах
}

\author{
$\underline{\text { Г.К. Алагашев }}^{1}$, В.П. Смаев ${ }^{1}$, А.А. Гулин ${ }^{2}$, А.Г. Охримчук ${ }^{1,3, *}$ \\ ${ }^{I}$ Российский Химико-Технологический Университет им. Д.И. Менделеева \\ ${ }^{2}$ Федеральный исследовательский иентр химической физики им. Н.Н. Семенова РАН \\ ${ }^{3}$ Институт Общей Физики РАН, им. А.М. Прохорова, НЦВО им. Е.М. Дианова \\ *E-mail: alagashevgrigory@gmail.com
}

DOI: 10.31868/RFL2020.34-35

Волноводные устройства на основе мягких стёкол, обладающих большим нелинейным показателем преломления, перспективны для интегральной нелинейной фотоники и фотоники среднего ИК, в частности, для генерации суперконтинуума в среднем ИК [1]. Прямая фемтосекундная лазерная позволяет создавать такие устройства, однако проектирование волноводов с заданными характеристиками в таких стёклах, и расчёт волноводных параметров затруднены из-за сложного профиля показателя преломления. Последнее обстоятельство повидимому связано с тем, что изменение показателя преломления обусловлено не только с изменением плотности стекла (как, например, при записи волноводов в кварцевом стекле), но и взаимной диффузией химических элементов из и в зону воздействия лазерного пучка (зона лазерной плазмы) [2].

$\mathrm{B}$ данной работе мы исследовали запись в объёме стекла состава $70 \mathrm{TeO}_{2}$ $22 \mathrm{WO}_{3}-8 \mathrm{Bi}_{2} \mathrm{O}_{3}$ пучком фемтосекундного лазера, сфокусированным объективом с $\mathrm{NA}=0.85$ в диапазоне частот повторения $50-1000 \mathrm{kHz}$. Для того, чтобы облегчить численное моделирование процесса и понимание механизма модификации, производилась запись в одной и той же точки стекла (то есть без сканирования образца относительно перетяжки лазерного пучка) но различным количеством импульсов и при различных частотах повторения. Пространственное распределение изменения показателя преломления в области модификации оценивалось с помощью количественной фазовой микроскопии $(\mathrm{QPm})$. На Рис.1 представлены зависимости максимальной вариации фазы прошедшего света, обусловленные изменением показателя преломления в области модификации, от количества лазерных импульсов.

Пространственное распределение концентраций элементов в области модификации исследовано методом время-пролётной масс-спектрометрии вторичных ионов (ToF-SIMS). Обнаружено существенное изменение концентраций $\mathrm{Bi}, \mathrm{W}$ и Те в области лазерного воздействия и его окрестности. $\mathrm{B}$ частности, концентрация ионов висмута уменьшается в области перетяжки лазерного пучка. Однако пространственное разрешение метода оказалось недостаточно, чтобы связать распределение изменения концентрации с профилем фазы. Поэтому были предприняты численные расчёты термической диффузии ионов. Диффузия моделировалась с помощью связанных уравнений теплопроводности и диффузии:

$$
\begin{aligned}
& \rho C_{p}(T) \frac{\partial T}{\partial t}+\nabla \cdot(-k(T) \nabla T)=F(t) \\
& \frac{\partial C}{\partial t}+\nabla \cdot\left(-D(T) \nabla C-C D_{T}(T) \nabla T\right)=0
\end{aligned}
$$

Температурные зависимости для теплоемкости $\left(C_{p}\right)$ и теплопроводности $(k)$ стекла в области $300-950 \mathrm{~K}$ взяты для близкого по составу стекла. Зависимость 
коэффициентов диффузии от температуры принята удовлетворяющей закону Аррениуса:

$$
D(T)=D_{0} \exp \left(-E_{a} / R T\right),
$$

где $R$ - универсальная газовая постоянная, $E_{a}$ - энергия активации диффузии. Коэффициент термодиффузии:

$$
D_{T}(T)=D(T) Q / R T^{2},
$$

где $Q$ - теплота переноса [3]. Воздействие импульсов лазера моделировалось через мощность нагрева $F(t)$, с пространственным распределением в виде обобщенного нормального распределения. Мы полагаем, что изменение показателя преломления пропорционально изменению относительной концентрации компонентов стекла. Форма экспериментальной зависимости фазы от количества импульсов аппроксимировалась расчётной зависимостью изменения концентрации от количества импульсов при варьировании параметров $E_{a}$ и $Q$. Хорошее согласие теории с экспериментом получено для импульсов с наибольшей энергией $E_{p}=90$ нДж (Рис.1). Для энергий 50 и 70 нДж и при количестве импульсов менее 10 теория предсказывает значительно более низкие значения изменения концентрации, чем необходимо для объяснения изменения фазы. Проведённые расчёты свидетельствуют, что перераспределение химических элементов вследствие диффузии даёт значительный вклад в изменение показателя преломления, но вместе с тем необходимо учесть другие факторы (например, изменение плотности вследствие деформации), чтобы объяснить изменение показателя преломления при небольших нагревах.

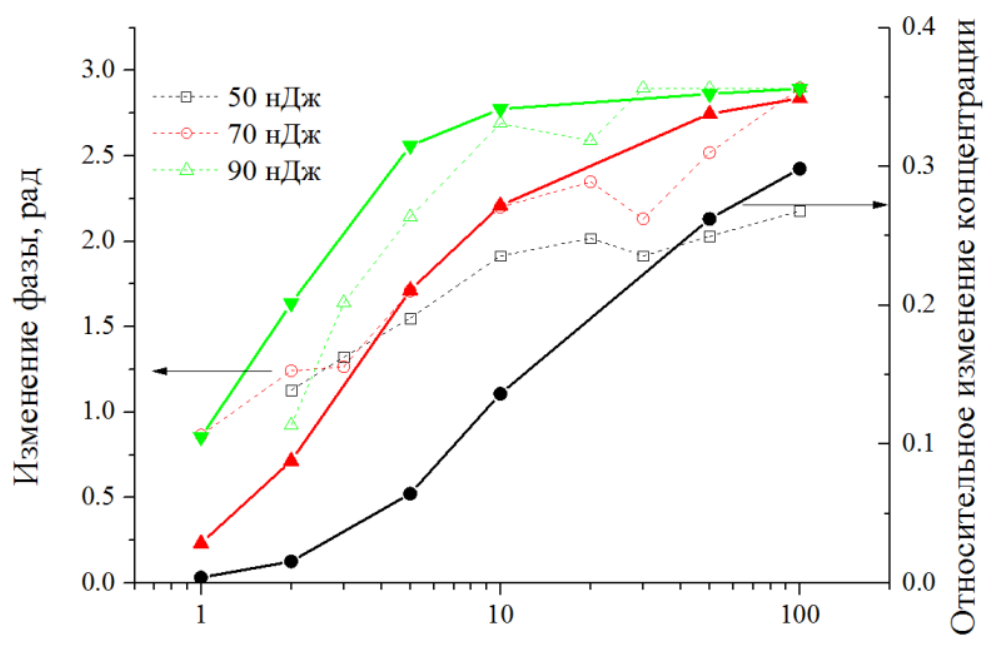

Количество импульсов

Рис.1 Сравнение измеренной вариации оптической фазы излучения прошедшего через модифицированные области (пунктир) и смоделированной концентрации ионов (сплошные линиии) при частоте повторения импульсов 1 MHz. $Q=10^{4}$ Дж/моль, $E_{a}=7 \cdot 10^{4}$ Дж/моль, $D_{0}=10$

$$
\mathrm{m}^{2} / \mathrm{c}, C(0)=2.5 \cdot 10^{3} \text { моль } / \mathrm{M}^{3}
$$

Исследования поддержаны РНФ, грант \#18-19-00733.

\section{Литература}

[1] A.G. Okhrimchuk, A.D. Pryamikov et al, J. Light. Technol. 38, 1492-1500 (2020)

[2] T.Gretzinger, T.T. Fernandez et al, Opt. Lett. 45, 3369 (2020)

[3] P. Shewmon, Diffusion in Solids (1963) 